\title{
Analisis Kepatuhan Atas Penerapan Internet Corporate Reporting (ICR) Pada Bank Umum Syariah Di Indonesia
}

\author{
Dessy Noor Farida \\ Fakultas Ekonomi dan Bisnis Islam, UIN Walisongo \\ *Email korenpondensi: dessy_nf@walisongo.ac.id
}

\begin{abstract}
In the digital business era, having a high-quality and effective website is one of the priority strategies for many companies. Companies that have information on the company's website can make it easier for users to find all the necessary information related to the company without incurring high costs. With corporate reporting, the company will present financial information in a timely manner to convince users of financial statements that the data available is relevant information. In order to increase transparency while increasing the access of shareholders and other stakeholders to the information of issuers or public companies OJK (Otoritas Jasa Keuangan) issues regulations related to the website of the issuer or public company. The results of this study indicate that Islamic banks have not utilized the facilities provided on the website optimally. This is indicated by the ICR index average of Islamic banks which is still in the range of 51.1. The highest ICR index is owned by Bank Muamalat Indonesia with a score of 73.97 and the lowest ICR index is owned by Bank Mega Syariah bank with a score of 36.99.
\end{abstract}

Keywords: Internet Corporate Reporting, information disclosure, website, compliance, Islamic banking JEL Clasification: Islamic Accounting

\begin{abstract}
Abstrak
Dalam era bisnis digital, memiliki situs web berkualitas tinggi dan efektif adalah salah satu strategi prioritas bagi banyak perusahaan. Perusahaan yang memiliki informasi di situs web perusahaan dapat membuatnya lebih mudah bagi pengguna untuk menemukan semua informasi yang diperlukan terkait dengan perusahaan tanpa menimbulkan biaya tinggi. Dengan pelaporan perusahaan, perusahaan akan menyajikan informasi keuangan secara tepat waktu untuk meyakinkan pengguna laporan keuangan bahwa data yang tersedia adalah informasi yang relevan. Untuk meningkatkan transparansi sambil meningkatkan akses pemegang saham dan pemangku kepentingan lainnya ke informasi emiten atau perusahaan publik OJK (Otoritas Jasa Keuangan) mengeluarkan peraturan yang terkait dengan situs web penerbit atau perusahaan publik. Hasil penelitian ini menunjukkan bahwa bank syariah belum memanfaatkan fasilitas yang disediakan di situs web secara optimal. Ini ditunjukkan oleh rata-rata indeks ICR bank syariah yang masih di kisaran 51.1. Indeks ICR tertinggi dimiliki oleh Bank Muamalat Indonesia dengan skor 73,97 dan indeks ICR terendah dimiliki oleh Bank Mega Syariah dengan skor 36,99.
\end{abstract}

Kata kunci: Internet Corporate Reporting, pengungkapan informasi, situs web, kepatuhan, perbankan syariah Klasifikasi JEL: Akuntansi Islam 


\section{Pendahuluan}

Pertumbuhan teknologi dan internet yang semakin cepat membawa perubahan cara bisnis perusahaan. Teknologi digunakan dengan efektif dan efisien dalam membantu kebutuhan berbagai hal oleh para penggunanya termasuk perusahaan. Pada tahun 2017, menurut eMarketer pengguna internet di Indonesia mencapai 112 juta orang. Diperkirakan pada tahun 2018, pengguna internet di dunia mencapai 3,6 miliar orang, yang setidaknya akan mengakses internet setidaknya sekali seiap satu bulan. Kemajuan teknologi dan semakin berkembangnya penggunaan internet di masyarakat mendorong perusahaan untuk melaporkan informasi keuangan dan non keuangannya secara langsung dan cepat untuk memenuhi kebutuhan para pengguna laporan keuangan di seluruh dunia. Hal ini memudahkan para pengguna laporan keuangan untuk dapat mengakses informasi yang mereka butuhkan secepat mungkin.

Dalam era digital business, memiliki website yang berkualitas tinggi dan efektif menjadi salah satu strategi prioritas bagi perusahaan (Debei, 2014). Menurut Almilia (2009), menempatkan informasi pada website perusahaan dapat mempermudah pengguna informasi dalam mencari segala informasi yang diperlukan terkait perusahaan tanpa mengeluarkan biaya yang cukup tinggi. Perusahaan yang memiliki teknologi tinggi akan melakukan pelayanan secara online dan menyajikan informasi keuangan secara tepat waktu untuk meyakinkan pengguna laporan keuangan bahwa data yang tersedia merupakan informasi yang relevan. Menurut Kieso et al (2011) banyak perusahaan sekarang ini menggunakan internet untuk menyediakan informasi yang lebih useful bagi para pengguna laporan keuangan. Perusahaan akan berusaha untuk memberikan informasi melalui internet untuk mendapatkan keuntungan seperti pemasaran yang bersifat global, mengurangi biaya untuk pendistribusian laporan keuangan dalam bentuk hard copy, dapat mengkomunikasikan informasi lebih luas dan dapat menjadi sarana untuk berinteraksi dengan para pemegang saham (Chiu, et al., 2002).

Internet dapat dijadikan sebagai media penyampaian informasi yang penting karena memiliki berbagai keunggulan seperti mudah menyebar, tidak mengenal batas, real time, berbiaya rendah dan mempunyai interaksi yang tinggi serta diintegrasikan dengan teks, angka, gambar, animasi, video dan suara. Bagi pihak perusahaan, hal ini dapat dijadikan sebagai keuntungan tersendiri, karena internet dapat dimanfaatkan sebagai media dalam menyediakan informasi kepada stakeholder mengenai gambaran kondisi perusahaan, informasi keuangan dan lain sebagainya melalui website perusahaan (Rizqiyah \& Lubis, 2017). Hal ini memberikan kemudahan akses bagi para stakeholder perusahaan untuk mendapatkan informasi lebih cepat dan dimanapun mereka berada, tanpa harus menunggu atau menghubungi pihak perusahaan.

Pengungkapan informasi perusahaan di internet, atau yang sering disebut Internet Corporate Reporting (ICR), merupakan penggunaan internet sebagai sarana yang dipilih oleh perusahaan untuk menyajikan lebih banyak informasi kepada stakeholder. Pengungkapan ICR akan lebih meningkatkan transparansi dan akuntabilitas perusahaan. Hal ini merupakan salah satu wujud penerapan good corporate governance yang berkualitas. Dua hal yang memastikan manajemen berjalan dengan baik adalah adanya kemudahan pemegang saham untuk memperoleh informasi yang benar dan tepat waktu serta adanya pengungkapan secara akurat, tepat waktu dan transparan terhadap semua informasi kinerja perusahaan, kepemilikan dan stakeholder (Kaihatu, 2006).

Pada tahun 2014, Otoritas Jasa Keuangan (OJK) dalam "Roadmap Tata Kelola Perusahaan Indonesia" telah merekomendasikan untuk mewajibkan perusahaan publik dalam mengungkapkan informasi material tertentu melalui website perusahaan, karena Pedoman Umum Good Corporate Governance (GCG) di Indonesia saat itu belum mewajibkan atau mendorong perusahaan untuk mengungkapkannya. BAPEPAM LK selaku pengatur pasar modal sebelumnya telah mewajibkan emiten atau perusahaan publik untuk memiliki situs web dan menyediakan informasi secara terbatas. Oleh karena itu, OJK telah menyusun Rancangan Peraturan Otoritas Jasa Keuangan tentang Situs Web emiten atau perusahaan publik yang dengan begitu menandakan adanya keseriusan OJK dalam mengatur penerapan IFR di Indonesia (Rizqiyah \& Lubis, 2017).

Dalam rangka meningkatkan transparansi sekaligus meningkatkan akses pemegang saham serta pemangku kepentingan lainnya atas informasi emiten atau perusahaan publik, maka OJK pada tahun 2015 telah menerbitkan Peraturan OJK Nomor 8/POJK.04/2015 tentang Situs Web Emiten Atau Perusahaan Publik (OJK, 2014). Dalam peraturan tersebut OJK mewajibkan setiap emiten untuk memiliki situs web perusahaan. Setiap emiten harus menyajikan semua informasi yang telah di atur oleh OJK, yang terdiri atas informasi umum emiten, infofrmasi bagi pemodal atau investor, informasi tata kelola perusahaan, dan informasi tanggung jawab sosial perusahaan. 
Di Indonesia, peran perbankan dalam perekonomian Indonesia lebih besar dibandingkan dengan lembaga keuangan bukan bank. Peran perbankan Indonesia mencapai $87 \%$ untuk memenuhi pendanaan khususnya perusahaan besar, sedangkan peran lembaga keuangan bukan bank hanya 13\% (Hardianto, et al., 2016). Dengan peran perbankan di Indonesia yang cukup besar, maka akan banyak stakeholder yang berkepentingan dengan informasi yang disajikan perbankan. Fungsi bank sebagai media intermediasi dalam menghimpun dana dari masyarakat dan menyalurkannya kembali, menuntut bank untuk dapat melakukan transparansi mengenai perkembangan usahanya kepada masyarakat luas.

Menurut Republika (2017), pada tahun 2016 pertumbuhan perbankan syariah mencapai $19,67 \%$ dan pangsa pasar perbankan syariah mencapai 5,12 $\%$, tertinggi sepanjang keberadaan perbankan syariah di Indonesia. Berdasarkan kajian awal tahun yang dilakukan oleh ISEFID (Islamic Economic Forum for Indonesian Development) perbankan syariah harus terus berbenah dan memperbaiki kualitas layanan dan jaringan. Hal ini dikarenakan peluang bank syariah masih cukup besar dan diharapkan bank syariah berperan dalam perekonomian nasional. Oleh karena itu, bank syariah tidak boleh terlepas dari perkembangan teknologi yang ada, karena dengan menerapkan ICR secara optimal, maka diharapkan dapat membantu sektor perbankan syariah dalam meningkatkan market share-nya.

Penelitian terkait dengan ICR di Indonesia telah banyak dilakukan. Penelitian yang dilakukan oleh (Almilia, 2009a) tentang analisa kualitas isi financial and sustainability reporting pada website perusahaan go public di Indonesia menemukan bahwa $62 \%$ perusahaan telah memiliki website dan banyak perusahaan yang belum memanfaatkan secara optimal pengungkapan informasi perusahaan melalui website baik untuk informasi keuangan dan keberlanjutan perusahaan. (Fikrisani, 2015) juga melakukan penelitian terkait dengan faktor-faktor yang mempengaruhi tingkat pengungkapan ICR pada perusahaan manufaktur pada tahun 2013. Penelitian ini membuktikan bahwa kepemilikan publik, ukuran auditor dan

Berdasarkan uraian diatas, maka rumusan permasalahan dari penelitian ini adalah sebagai berikut:

a. Bagaimana tingkat kepatuhan Bank Umum Syariah di Indonesia terkait dengan aturan leverage tidak berpengaruh terhadap tingkat pengungkapan ICR, sedangkan ukuran perusahan dan tambahan modal disetor berpengaruh signifikan terhadap pengungkapan ICR. Penelitian yang dilakukan oleh Rizqiyah \& Lubis (2017) tentang penerapan internet financial reporting pada bank umum syariah di Indonesia menemukan bahwa Bank BNI Syariah berada pada peringkat pertama dalam skore IFR sebesar $63 \%$ darii 70 item yang diujikan, diikuti BSM, BRIS dan Bank Panin. Rata-rata skor IFR perbankan syariah adalah 55\%.

Penelitian terdahulu dilakukan sebelum di keluarkannya Peraturan OJK Nomor 8/POJK.04/2015 terkait dengan kewajiban para emiten untuk memiliki website. Sehingga ketika penelitian terdahulu dilakukan sifatnya masih penyajian secara sukarela. Setelah dikeluarkannya aturan tersebut, maka semua perusahaan yang terdaftar di Bursa Efek Indonesia wajib untuk memiliki situs web perusahaan. Penelitian ini dilakukan untuk mengetahui bagaimana penerapan aturan OJK, yang telah di terapkan selama 2 tahun dari penetapan peraturan tersebut, khususnya di Bank Syariah yang ada di Indonesia.

\section{Rumusan Masalah}

Internet Corporate Reporting (ICR) merupakan salah satu media bagi perusahaan untuk memberikan informasi kepada stakeholder secara transparan dan kredibel melalui website perusahaan. Di Indonesia telah diatur oleh OJK maupun BAPEPAM LK terkait dengan kewajiban perusahaan publik untuk memiliki website perusahaan dan memberikan laporan yang diperlukan oleh para stakeholder. Sehingga akan meningkatkan transparansi dan meningkatkan kepercayaan para pemegang saham terhadap perusahaan.

Perkembangan bank syariah yang masih potensial di Indonesia dan peran penting bank syariah sebagai lembaga intermediasi dalam menghimpun dana dari masyarakat dan menyalurkannya kembali, menuntut bank untuk dapat melakukan transparansi mengenai perkembangan usahanya kepada masyarakat luas.

kewajiban perusahaan publik untuk memiliki website?

b. Bagaimana tingkat pengungkapan Bank Umum Syariah terkait dengan informasi yang wajib di sajikan didalam website? 


\section{Tujuan Dan Manfaat Penelitian}

Tujuan dan manfaat dari penelitian ini adalah

a. Untuk mengetahui tingkat kepatuhan Bank Umum Syariah di Indonesia terkait dengan aturan kewajiban perusahaan publik untuk memiliki website.

b. Untuk mengetahui tingkat pengungkapan Bank Umum Syariah terkait dengan informasi yang wajib di sajikan didalam website.

\section{Tinjauan Pustaka \\ Compliance Theory}

Compliance diartikan sebagai suatu kepatuhan yang didasarkan pada harapan akan suatu imbalan dan usaha untuk menghindarkan diri dari hukuman yang mungkin dijatuhkan (Kelman, 1956). Menurut Tim penyusun Kamus Pusat Bahasa, kepatuhan berarti sifat patuh, ketaatan. Kepatuhan merupakan bentuk perilaku yang berasal dari dorongan dalam diri manusia.

Teori kepatuhan dapat mendorong seseorang untuk lebih mematuhi peraturan yang berlaku. Demikian juga dengan peraturan yang telah dikeluarkan oleh OJK, semua perusahaan publik akan berupaya untuk mematuhi semua aturan yang berlaku. Dalam aturan tersebut, Otoritas Jasa Keuangan juga mengatur terkait dengan ketentuan sanksi yang diberikan kepada pihak yang tidak mematuhi peraturan. Saksi yang diberikan dapat berupa peringatan tertulis, denda, pembatasan kegiatan usaha, pembekuan kegiatan usaha pencabutan izin usaha, pembatalan persetujuan dan pembatalan pendaftaran. Sehingga diharapkan dengan adanya sanksi tersebut, dapat mengurangi ketidakpatuhan dari perusahaan publik yang listing di Bursa Efek Indonesia.

\section{Agency Theory}

Jensen \& Meckling (1976) menyatakan bahwa hubungan keagenan adalah sebuah kontrak antara manajer dan investor. Dalam teori ini, investor sebagai principal merupakan pihak yang memberikan mandat kepada pihak lain yang disebut dengan agen (manajer) untuk dapat bertindak atas nama agen tersebut. Perbedaan antara prinsipal dan agen akan timbul ketika investor tidak dapat dengan mudah untuk memantau kinerja manajer. Hal ini dikarenakan investor tidak memiliki informasi yang cukup mengenai kinerja agen, maka investor tidak pernah merasa pasti bagaimana usaha manajemen memberikan kontribusi pada hasil akhir perusahaan. Situasi yang demikian disebut sebgaai asimetri informasi.

Berdasarkan teori keagenan, laporan perusahaan dibuat oleh pihak manajemen sebagai bentuk pertanggung jawaban manajemen kepada para pemegang saham. Dalam kedudukannya sebagai pihak yang memiliki informasi dan terlibat secara langsung dalam aktivitas perusahaan, manajemen memiliki intensif untuk melaporkan segala sesuatu yag dapat memaksimalkan utilitas dirinya. Dalam konsep teori keagenan, asimentri informasi mendorong dan memotivasi manajer untuk bersikap oportunistis, yaitu memanipulasi informasi kinerja yang dipublikasikannya.

\section{Signaling Theory}

Signaling Theory atau teori signal menjelaskan bahwa perusahaan harus memanfaatkan informasi laporan keuangan untuk memberi sinyal positif maupun negatif kepada pihak eksternal (Wolk,2001). Dorongan untuk mengungkapkan informasi ini muncul dari adanya informasi yang asimetri antara pihak manajemen dengan para pemegang saham, dimana manajemen akan mengetahui lebih banyak informasi dibandingkan dengan pemegang saham. Sehingga akan memunculkan adanya agency cost. Agency cost ini akan dapat di minimalisir salah satunya dengan pengungkapan informasi perusahaan yang transparan dan akuntabel.

Signaling theory dapat digunakan untuk memprediksi kualitas pegungkapan perusahaan, yaitu dengan penggunaan internet sebagai media pengungkapan perusahaan dapat meningkatkan kualitas pengungkapan (Almilia, 2009b). Informasi keuangan maupun informasi non keuangan akan di ungkapkan oleh perusahaan untuk memberikan sinyal kepada para investor. Informasi yang positif dan dapat dipercaya akan mengurangi ketidakpastian mengenai prospek perusahaan di masa yang akan datang sehingga dapat meningkatkan kepercayaan dan kredibilitas perusahaan.

\section{Pengungkapan}

Secara konseptual, pengungkapan merupakan bagian integral dari pelaporan keuangan. Sedangkan secara teknis, pengungkapan merupakan langkah akhir dari suatu proses 
akuntansi yaitu penyajian informasi dalam bentuk seperangkat penuh statement keuangan. Menurut Suwardjono pengungkapan sering pula dimaknai sebagai penyediaan informasi lebih dari apa yang dapat disampaikan dalam bentuk statement keuangan formal (Rizqiyah \& Lubis, 2017). Terdapat dua jenis pengungkapan perusahaan yaitu pengungkapan wajib (mandatory disclosure) dan pegungkapan sukarela (voluntary disclosure).

Pengungkapan wajib merupakan jenis pengungkapan yang telah diatur menurut undangundang pada setiap negara. Di Indonesia, pengungkapan wajib diatur dalam Keputusan Ketua BAPEPAM-LK Nomor KEP-431/BL/2012 yang menjelaskan tentang penyampaian laporan tahunan emiten atau perusahaan publik. Peraturan ini menjelaskan kewajiban perusahaan untuk memiliki website resmi, maksimal satu tahun sejak diberlakukannya peraturan ini, serta kewajiban untuk menyampaikan laporan tahunan dan memasukkannya ke dalam website perusahaan (Fikrisani, 2015). Aturan ini juga diperkuat dengan dikeluarkannya atauran OJK nomor 8/POJK.04/2015 yang berisi kewajiban emiten untuk memliki situs web dan informasi apa saja yang harus dimuat dalam website tersebut. Ada 4 informasi yang wajib dimuat dalam situs web emiten yaitu informasi umum emiten, informasi bagi pemodal atau investor, informasi tata kelola perusahaam dam informasi tanggung jawab sosial perusahaan.

Pengungkapan sukarela merupakan penyampaian informasi secara lebih luas diluar pengungkapan wajib. Perusahaan secara penih memegang kendali mengenai hal apa saja yang ingin diungkapkan. Berkembangnya kebutuhan akan informasi yang lengkap, menyeluruh, lebih detail dan tepat waktu dari investor semakin mendorong perusahaan untuk mengembangkan tingkat pengungkapan sukarela. Minat investor yang tinggi terhadap informasi sukarela dari perusahaan, biasanya yang bersifat good news, sangat mempengaruhi keputusan dan pandangan investor terhadap perusahaan tertentu (Fikrisani, 2015).

\section{Internet Corporate Reporting}

Internet Corporate Reporting merupakan pengungkapan informasi perusahaan melalui internet. ICR merupakan salah satu contoh pengungkapan sukarela yang dilakukan oleh perusahaan. Dengan menggunakan ICR perusahaan dapat memberikan informasi baik keuangan maupun non keuangan kepada masyarakat luas melalui website pribadi perusahaan. Sebagaimana karakteristik pengungkapan sukarela, praktik ICR di berbagai negara akan berbeda-beda karena disesuaikan dengan kebutuhan dan keinginan masing-masing perusahaan. Pemerintah Indonesia, pada tahun 2015, telah mengeluarkan peraturan terkait dengan wajibnya perusahaan publik untuk memiliki website, maka pengungkapan melalui internet merupakan peraturan yang wajib, bukan lagi peraturan yang bersifat sukarela. Hal ini diharapkan dapat meningkatkan transparansi sekaligus meningkatkan akses pemegang saham serta pemangku kepentingan lainnya atas informasi emiten atau perusahaan publik.

ICR memiliki banyak keunggulan seperti tingginya minat masyarakat terhadap kemajuan teknologi dan internet, kemudahan dalam pengoperasian, rendahnya biaya, akses yang cepat dan fleksibel. Pada penelitian ini ICR dinilai dengan menggunakan indeks yang menganalisis kelengkapan isi yang ada didalam website perusahaan yang berbasis html.

\section{Penelitian Terdahulu}

Penelitian yang terkait dengan Internet Corporate Reporting sudah cukup banyak dilakukan di Indonesia. Penelitian yang dilakukan oleh (Almilia, 2009b) tentang Analisa Kualitas Isi Financial dan Sustainability Reporting Pada Website Perusahaan Go Public Di Indonesia menemukan bukti bahwa $62 \%$ perusahaan telah memiliki website dan banyak perusahaan yang belum memanfaatkan secara optimal pengungkapan informasi perusahaan melalui website baik untuk informasi keuangan dan keberlanjutan perusahaan. Penelitian ini mengukur kualitas isi informasi financial dan sustainability reporting dengan menggunakan indeks Cheng et al (2000) dan Lymer et al (1999).

Fikrisani (2015) juga melakukan penelitian terkait dengan faktor-faktor yang mempengaruhi tingkat pengungkapan ICR pada perusahaan manufaktur pada tahun 2013. Penelitian ini membuktikan bahwa kepemilikan publik, ukuran auditor dan leverage tidak berpengaruh terhadap tingkat pengungkapan ICR, sedangkan ukuran perusahan dan tambahan modal disetor berpengaruh signifikan terhadap pengungkapan ICR. 
Penelitian yang dilakukan oleh Rizqiyah \& Lubis (2017) tentang penerapan internet financial reporting pada bank umum syariah di Indonesia menemukan bahwa Bank BNI Syariah berada pada peringkat pertama dalam skore IFR sebesar 63\% dari 70 item yang diujikan, diikuti BSM, BRIS dan Bank Panin. Rata-rata skor IFR perbankan syariah adalah $55 \%$.

\section{Metode Penelitian}

\section{Jenis Penelitian}

Penelitian ini merupakan penelitian studi deskriptif (descriptive study) yaitu penelitian yang bertujuan untuk menjelaskan, meringkas berbagai kondisi, situasi atau berbagai variabel yang timbul di masyarakat yang menjadi objek penelitian itu berdasarkan apa yang terjadi. Kemudian mengangkat kepermukaan karakter atau gambaran tentang ondisi situasi ataupun variabel tersebut (Bungin, 2008). Berdasarkan jenis penelitian ini, maka penelitian ini hanya menggambarkan bagaimana tingkat kepatuhan bank syariah di Indonesia terkait dengan Peraturan OJK Nomor 8/POJK.04/2015 tentang Situs Web Emiten Atau Perusahaan Publik. Peraturan tersebut berlaku per tahun 2015, dan diharapkan selama kurang lebih 2 tahun merupakan waktu yang cukup untuk emiten menjalankan peraturan tersebut.

\section{Pemilihan Sampel}

Populasi dalam penelitian ini adalah seluruh bank umum syariah yang ada di Indonesia. Berdasarkan data statistik Perbankan Syariah per Januari 2017 jumlah bank Umum Syariah (BUS) adalah sejumlah 12 bank. Sedangkan teknik pemilihan sampel yang digunakan adalah dengan metode purposive sampling dimana peneliti memberikan kriteria dalam penentuan sampel yang akan digunakan sebagai berikut :

1. Bank umum syariah yang memiliki website resmi yang aktif dan tidak dalam perbaikan.

2. Bank umum syariah yang telah berdiri lebih dari dua tahun.

Data yang digunakan adalah data sekunder berupa keterangan/ informasi keuangan dan non keuangan yang bersumber dari website resmi masing-masing BUS. Alamat website masingmasing BUS diambil dari statistik data alamat BUS oleh OJK dan melalui bantuan search engine.

\section{Item Indikator Pengungkapan}

Item indikator pengungkapan yang digunakan adalah berdasarkan Peraturan OJK nomor 8/POJK.04/2015 tentang Situs Web Emiten atau Perusahaan Publik. Informasi yang wajib dimuat dalam website perusahaan kurang lebih meliputi empat item yaitu informasi umum emiten atau perusahaan publik (12 item), informasi bagi pemodal atau investor (45 item), informasi tata kelola perusahaan (12 item) dan informasi tanggungjawab sosial perusahaan (4 item).

\section{Tenik Analisis}

Teknik analisis data pada penelitian ini dilakukan dengan cara scoring. Pada teknik scoring ini tidak dibedakan bobot untuk setiap item pengungkapan. Tahapan-tahapan dalam menganalisis data pada penelitian ini yaitu :

1. Memberikan skor untu setiap item variabel yang diungkapkan melalui website bank, jika item tersebut diungkapkan maka diberi nilai skor satu (1) dan jika tidak diungkapkan akan diberikan skor nol (0).

2. Skor yang telah diperoleh kemudian dijumlahkan untuk mendapatkan total skor pengungkapan masing-masing bank.

3. Menghitung skor kelengkapan pengungkapan dengan menggunakan metode pehitungan yang digunakan oleh Khan dan Ismail (2011) yang cara perhitungannya sama seperti indeks pengungkapan pada umumnya, yaitu dengan membagi total skor yang diperoleh dengan skor maksimal yang dapat diperoleh bank apabila mengungkapkan keseluruhan item.

Rumus :

ICR Indeks =

Total skor yang diperoleh perusahaan total skor maksimas

4. Melakukan eksplorasi terhadap hasil penelitian sesuai dengan hasil yang dipaparkan pada penelitian terdahulu dan memberikan kesimpulan secara umum dari hasil penelitian.

\section{Pembahasan}

Bank Umum Syariah mempunyai peran sebagai lembaga intermediasi dalam menghimpun dana dari masyarakat yang memiliki kelebihan dana dan menyalurkan dana tersebut kepada masyarakat yang membutuhkan dana. Sehingga 
dengan perannya tersebut, bank dituntut memiliki transparansi yang tinggi terkait dengan pertanggungjawaban dana tersebut. Dalam rangka meningkatkan transparansi sekaligus meningkatkan akses pemegang saham serta pemangku kepentingan lainnya atas informasi emiten atau perusahaan publik, maka OJK pada tahun 2015 telah menerbitkan Peraturan OJK Nomor 8/POJK.04/2015 tentang Situs Web Emiten Atau Perusahaan Publik. Oleh karena itu, dalam penelitian ini akan dilihat bagaimana luas pengungkapan informasi yang telah dilakukan oleh bank Umum syariah terhadap aturan baru yang dikeluarkan oleh OJK pada tahun 2015 lalu.

Dari data yang diperoleh, terdapat 1 bank yang websitenya tidak dapat diakses yaitu bank panin syariah, sehingga total sampel yang di pakai dalam penelitian ini adalah sebanyak 10 Bank Umum Syariah. Hasil perhitungan skor ICR dari keseluruhan sampel yang dipakai dapat terlihat dari grafik 1. Dari data tersebut diketahui skor yang diraih oleh masing-masing BUS cukup bervariasi. Dimana ICR index yang tertinggi diraih oleh Bank Muamalat sebesar $73.97 \%$ atau terdapat 54 item yang diungkapkan dalam website dari total pengungkapan sebanyak 73 item. Kemudian diikuti Bank Syariah Mandiri dan Bank Jabar Banten Syariah yang masing-masing mendapatkan skor ICR Index sebesar 69,86\% dan 60,27\%. Sedangkan skor ICR index terendah adalah Bank
Victoria Syariah sebesar 34,25\% atau sebanyak 25 item saja yang diungkapkan dalam website perusahaan. Dari grafik dibawah dapat dilihat bahwa pengungkapan didalam website perusahaan masing-masing masih cukup rendah, dimana mayoritas BUS memiliki ICR Index pada kisaran $51,1 \%$. Hasil ini tentu sangat tidak memuaskan dan menunjukkan rendahnya BUS dalam menerapkan aturan baru yang dikeluarkan oleh OJK. Dalam jangka waktu 2 tahun ternyata masih banyak yang belum diungkapkan didalam website sesuai dengan aturan dari OJK.

Grafik 1 . Skor ICR Indeks BUS Keseluruhan

\section{ICR Indeks}

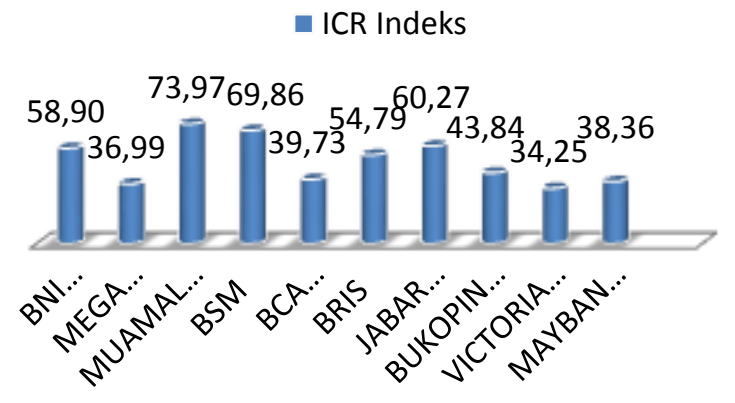

Sumber : data diolah, 2018

Tabel 1. Data Jumlah Item Pengungkapan di dalam Website Bank Umum Syariah

\begin{tabular}{|c|c|c|c|c|c|c|c|c|c|c|c|}
\hline \multirow[b]{2}{*}{ NO } & \multirow[b]{2}{*}{ KETERANGAN } & \multicolumn{10}{|c|}{ NAMA BANK UMUM SYARIAH } \\
\hline & & $\begin{array}{c}\text { BNI } \\
\text { Syar } \\
\text { iah }\end{array}$ & $\begin{array}{l}\text { Meg } \\
\text { a } \\
\text { Syari } \\
\text { ah }\end{array}$ & $\begin{array}{l}\text { Muamala } \\
\mathrm{t} \\
\text { Indonesi } \\
\mathrm{a}\end{array}$ & $\begin{array}{l}\text { BS } \\
\text { M }\end{array}$ & $\begin{array}{c}\text { BCA } \\
\text { Syaria } \\
\text { h }\end{array}$ & BRIS & $\begin{array}{c}\text { Jabar } \\
\text { Banten } \\
\text { Syaria } \\
\text { h }\end{array}$ & $\begin{array}{c}\text { Bukopi } \\
n \\
\text { Syariah }\end{array}$ & $\begin{array}{c}\text { Victori } \\
\text { a } \\
\text { Syariah }\end{array}$ & $\begin{array}{l}\text { Mayb } \\
\text { ank } \\
\text { Syari } \\
\text { ah }\end{array}$ \\
\hline 1 & $\begin{array}{l}\text { Jml item } \quad \text { yg } \\
\text { diungkapkan } \\
\text { langsung di dalam } \\
\text { website }\end{array}$ & 25 & 9 & 17 & 17 & 11 & 17 & 21 & 9 & 9 & 9 \\
\hline 2 & $\begin{array}{lrr}\text { jml item } & \text { yang } \\
\text { diungkapkan } & \text { tidak } \\
\text { langssung di } & \text { website } \\
\text { (Annual } & \text { report/ } \\
\text { laporan } & \text { GCG/RUPS } \\
\text { dll) } & \\
\end{array}$ & 18 & 18 & 37 & 34 & 18 & 23 & 23 & 23 & 16 & 19 \\
\hline & $\begin{array}{l}\text { Total informasi } \\
\text { yang disajikan }\end{array}$ & 43 & 27 & 54 & 51 & 29 & 40 & 44 & 32 & 25 & 28 \\
\hline
\end{tabular}

Sumber : data diolah, 2018 
Dari hasil penelitian dapat diketahui bahwa tidak semua informasi yang disajikan langsung dapat di peroleh oleh pengguna informasi. Ada beberapa informasi yang harus dicari dulu oleh pengguna informasi, sehingga hal ini dapat menyulitkan para pengguna dalam mencari informasi yang dibutuhkan. Seperti dalam tabel diatas, dapat dilihat bahwa hampir sebagian besar informasi tersebut tersebar di beberapa laporan yaitu di annual report, laporan good corporate governance dan RUPS. Pada Bank Muamalat yang menyajikan jumlah informasi terbanyak yaitu sebanyak 54 item, hanya sebanyak 17 item saja yang langsung bisa diakses di dalam web, sedangkan sisanya sebesar 37 item terdapat di annual report, GCG report dan RUPS.
Dari data diatas juga dapat kita lihat hanya BNI Syariah saja yang lebih banyak mengungkapkan item langsung diwebsite resmi yaitu sebanyak 25 item, sedangkan sisanya harus dicari di laporan perusahaan lainnya sebanyak 18 item. Kemudahan pengguna dalam mencari informasi juga merupakan hal penting yang perlu diperhatikan oleh BUS, jika informasi yang di butuhkan oleh pengguna lebih mudah dicari di dalam website dan tersedia di dalam menu website, maka kepercayaan pengguna terhadap BUS akan semakin tinggi juga.

Dibawah ini adalah rincian hasil perolehan skor ICR pada masing-masing BUS serta untuk masing-masing indikator pengungkapan :

Tabel 2. Data Pengungkapan Informasi BUS berdasarkan masing-masing Indikator

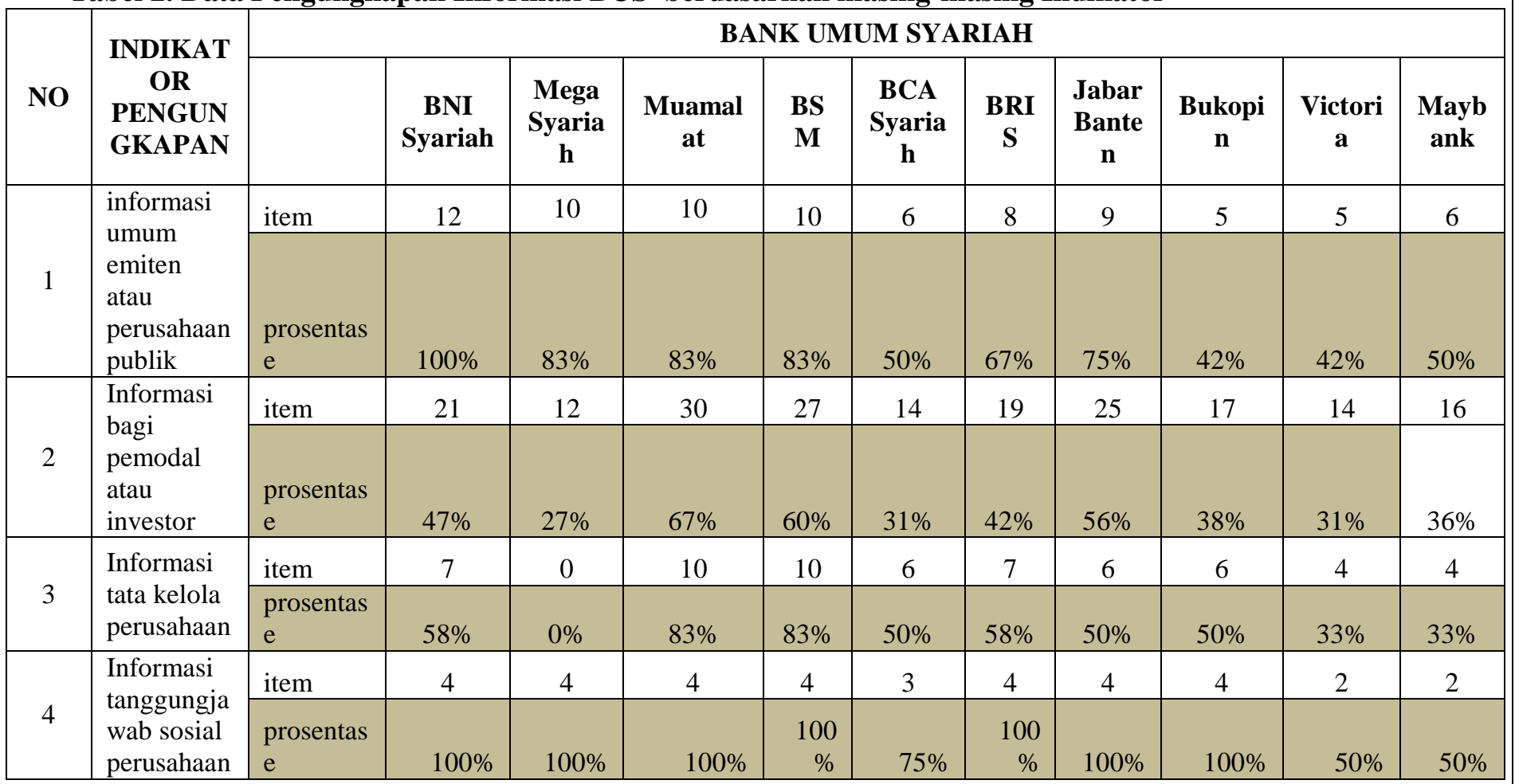

\section{Sumber : data diolah, 2018}

Dari data diatas dapat dilihat informasi yang banyak disajikan masing-masing BUS adalah pengungkapan terkait informasi tanggungjawab sosial perusahaan. Hampir semua BUS mengungkapkan informasi CSR-nya di dalam website resmi. Terlihat hampir semua BUS mengungkapkan semua item, sehingga mencapai prosentase pengungkapan $100 \%$. Sedangkan untuk informasi umum emiten atau perusahaan publik, yang mengungkapkan hampir semua item adalah BNI Syariah, diikuti Bank Mega Syariah, Bank Muamalat, BSM dan Bank Jabar Banten Syariah.

Untuk indikator informasi bagi pemodal atau investor, tidak ada BUS yang mencapai pengungkapan $100 \%$. Hanya ada 2 BUS yang mencapai pengungkapan diatas 50\% yaitu Bank Muamalah dan BSM yang masing-masing mengungkapkan sebanyak $67 \%$ dan $60 \%$. Hampir 
sebagian besar BUS mengungkapkan informasi bagi pemodal atau investor masih di bawah $50 \%$. Hal ini tentunya sangat memprihatinkan, mengingat investor adalah salah satu bagian terpenting bagi berkembangnya BUS. Di era teknologi yang sudah cukup tinggi ini, diharapkan semua informasi yang dibutuhkan oleh investor dapat diperoleh dengan mudah dan tepat waktu, sehingga informasi yang investor dapatkan akan lebih relevan dalam pengambilan keputusannya. Selain itu semakin banyak informasi yang dapat diakses oleh investor, maka tingkat transparansi laporan cenderung lebih tinggi dibandingkan dengan perusahaan yang menyajikan sedikit informasi di dalam websitenya.

\section{Informasi Umum Emiten Atau Perusahaan Publik}

Dari data diatas dapat dilihat, dari beberapa komponen yang harus diungkapkan terkait dengan informasi umum emiten/ perusahaan public, komponen yang paling banyak diungkapkan oleh BUS adalah riwayat singkat perusahaan, nomor telepon dan alamat surat serta nama dan alamat kantor pusat atau kantor perwakilan emiten. Sedangkan untuk informasi terkait dengan akuntan public, pemeringkatan efek, wali amanat dan biro administrasi serta dokumen anggaran dasar hanya adda 3 BUS yang mengungkapkan dalam website maisng-masing perusahaan. Dapat disimpulkan bahwa untuk informasi umum emiten sebagian besar BUS telah mengungkapkan di dalam website-nya. Hal ini memudahkan banyak pihak yang berkepentingan untuk mengetahui informasi umum perusahaan.

\section{Informasi Bagi Pemodal Atau Investor}

Komponen informasi bagi pemodal atau investor merupakan item yang paling banyak disarankan untuk di ungkapkan dalam website perusahaan. Untuk pengungkapan laporan keuangan hampir semua BUS sudah mengungkapkan dalam website perusahaan, sedangkan untuk informasi prospek penawaran umum tidak ada satupun BUS yang mengungkapkan. Untuk informasi Ikhtisar data keuangan dalam bentuk perbandingan, banyak BUS yang sudah mengungkapkan namun pengungkapannya tidak langsung dapat dilihat di website perusahaan, tetapi pengguna website harus membuka annual report terlebih dahulu untuk mengetahui ikhtisar data keuangan perusahaan.

Untuk informasi RUPS, hanya sebagian BUS yang menyajikan di dalam websitenya. Item yang banyak di ungkapkan terkait dengan informasi RUPS adalah terkait dengan ringkasan risalah RUPS. Hal ini cukup menyulitkan para investor untuk mengetahui informasi yang dibutuhkan untuk pengambilan keputusan. Demikian juga untuk informasi saham dan informasi obligasi/sukuk, tidak banyak BUS yang mengungkapkan terkait dengan item tersebut. Untuk informasi terkait aksi korporasi yang dilakukan oleh emiten juga hanya sedikit BUS yang mengungkapkan dalam website perusahaan. Kesimpulan yang dapat diambil dari data yang diperoleh adalah pengungkapan terkait informasi bagi pemodal atau investor terlihat sangan minim sekali diungkapkan oleh BUS. Hal ini cukup memprihatinkan karena informasi tersebut cukup penting untuk pengambilan keputusan para investor.

\section{Informasi Tata Kelola Perusahaan}

Dari data yang diperoleh, ada beberapa item yang tidak diungkapkan BUS dalam websitenya yaitu kebijakan terkait seleksi pemasok dan hak kreditur serta kebijakan dalam pemningkatan kemampuan vendor. Untuk item-item yang lainnya, ada sebagian BUS yang sudah mengungkapkan, tetapi tidak secara langsung didalam website, jadi pengguna laporan keuangan harus membuka terlebih dahulu annual report perusahaan pada bagian laporan tata kelola perusahaan. Hal ini tentunya kurang efektif, dimana pengguna laporan harus mencari terlebih dahulu informasi yang mereka butuhkan terkait dengan tata kelola perusahaan.

\section{Informasi Tanggungjawab Sosial Perusahaan}

Item yang paling banyak diungkapkan oleh BUS adalah terkait dengan pengungkapan praktik ketenagakerjaan, kesehatan dan keselamatan kerja serta pegembangan social dan kemasyarakatan. Sedangkan untuk item lingkungan hidup hanya ada 7 BUS yang mengungkapkan di dalam websitenya. Dan hanya 8 BUS yang mengungkapkan tanggungjawab produk dan atau layanan disertai dengan informasi pendukungnya. Jika dilihat didalam websitenya, rata-rata perbankan Syariah sudah mengungkapkan kegiatan yang berhubungan 
dengan CSR-nya dengan cukup lengkap, yaitu terkait dengan bentuk program CSR beserta fotofoto kegiatan.

Dibawah ini adalah table yang terkait dengan peringkat pengungkapan informasi di website masing-masing BUS di Indonesia. Dengan adanya peringkat di bawah ini, masing-masing BUS dapat mengetahui kualitas dan kuantitas informasi yang disajikan di dalam website resmi yang dimiliki masing-masing perusahaan. Dengan begitu, diharapkan BUS dapat meningkatkan ataupun mempertahankan kualitas yang telah dimiliki dengan cara memaksimalkan penggunaan website untuk memberikan informasi kepada pemangku kepentingan. Sehingga informasi yang disajikan dapat membantu pemangku kepentingan untuk pengambilan keputusan dengan lebih akurat.

Tabel 3. Peringkat skor ICR BUS di Indonesia

\begin{tabular}{|c|c|c|c|}
\hline PERINGKAT & $\begin{array}{l}\text { NAMA } \\
\text { BANK }\end{array}$ & $\begin{array}{c}\text { ICR } \\
\text { INDEX } \\
(\%)\end{array}$ & $\begin{array}{l}\text { JML } \\
\text { ITEM }\end{array}$ \\
\hline 1 & $\begin{array}{l}\text { PT. Bank } \\
\text { Muamalat } \\
\text { Indonesia }\end{array}$ & 73.97 & 54 \\
\hline 2 & $\begin{array}{l}\text { PT.Bank } \\
\text { Syariah } \\
\text { Mandiri }\end{array}$ & 69.86 & 51 \\
\hline 3 & $\begin{array}{l}\text { Bank } \\
\text { JABAR } \\
\text { Banten }\end{array}$ & 60.27 & 44 \\
\hline 4 & $\begin{array}{l}\text { PT. Bank } \\
\text { BNI Syariah }\end{array}$ & 58.90 & 43 \\
\hline 5 & $\begin{array}{l}\text { PT. Bank } \\
\text { BRISyariah }\end{array}$ & 54.79 & 40 \\
\hline 6 & $\begin{array}{l}\text { PT. Bank } \\
\text { Syariah } \\
\text { Bukopin }\end{array}$ & 43.84 & 32 \\
\hline 7 & $\begin{array}{l}\text { PT. Bank } \\
\text { BCA } \\
\text { Syariah }\end{array}$ & 39.73 & 29 \\
\hline 8 & $\begin{array}{l}\text { PT. Bank } \\
\text { Maybank } \\
\text { Syariah } \\
\text { Indonesia }\end{array}$ & 38.36 & 28 \\
\hline 9 & $\begin{array}{l}\text { PT. Bank } \\
\text { Mega } \\
\text { Syariah }\end{array}$ & 36.99 & 27 \\
\hline 10 & $\begin{array}{l}\text { PT. Bank } \\
\text { Victoria } \\
\text { Syariah }\end{array}$ & 34.25 & 25 \\
\hline
\end{tabular}

\section{Kesimpulan}

Dari 10 BUS yang dijadikan sampel penelitian, rata-rata perusahaan sudah mengungkapkan beberapa informasi yang harus diungkapkan sesuai dengan aturan yang telah dikeluarkan oleh OJK. Dari sampel penelitian, ICR Index terendah adalah $34,25 \%$ dan yang tertinggi adalah $73,97 \%$, dengan rata-rata ICR index adalah $51,10 \%$ (37 item). Hal ini menunjukkan bahwa informasi yang diungkapkan di dalam website perusahaan masih cukup minim jika mengacu pada aturan OJK. Hal ini terlihat dari rata-rata ICR index yang masih dikisaran 51,10\%.

Jika dilihat dari data yang diperoleh, beberapa BUS sudah cukup luas dalam mengungkapkan informasi yang dimilikinya. Hanya ada 5 BUS yang mencapai ICR Index diatas 50\%, sedangkan sisanya hanya berada di bawah 50\%. Hal ini menunjukkan bahwa BUS kurang dapat memanfaatkan kelebihan fiture yang disediakan oleh website. Sebagian besar perusahaan masih menyajikan informasi didalam annual report dan dilaporan perusahaan lainnya. Sehingga hal ini sedikit menyulitkan pengguna laporan keuangan karena harus mendownload terlebih dahulu laporan tersebut dan masih harus mencari informasi yang mereka butuhkan.

Kepatuhan BUS terhadap aturan yang telah dikeluarkan oleh OJK, yaitu terkait dengan peraturan OJK Nomor 8/POJK.04/2015 tentang Situs Web Emiten Atau Perusahaan Publik sudah cukup baik walaupun masih ada beberapa item yang belum diungkapkan secara langsung dalam website perusahaan. Diharapkan Bank Syariah di Indonesia dapat memaksimalkan penggunaan website perusahaan untuk memberikan informasi yang relevan dan akurat serta tepat waktu, sehingga hal ini dapat meningkatkan transparansi sekaligus meningkatkan akses pemegang saham serta pemangku kepentingan lainnya atas informasi emiten atau perusahaan publik.

Sebagaimana penelitian empiris lainnya, hasil penelitian ini juga memiliki keterbatasan. Keterbatasan penelitian ini adalah adanya unsur subjektivitas peneliti pada saat mengidentifikasi komponen-komponen ICR dari official website perusahaan. Sehingga ada peluang terjadi perbedaan persepsi diantara satu dengan yang lain saat menentukan apakah item tertentu diungkapkan atau tidak. Saran yang didasarkan dari keterbatasan tersebut adalah penggunaan 
content analysis untuk penelitian selanjutnya sebaiknya di lakukan lebih dari satu orang, sehingga dapat mengurangi subjektivitas peneliti yang pada akhirnya dapat menyebabkan kurang maksimalnya hasil penelitian.

\section{Referensi}

Almilia, L. S. (2009a). Analisa Komparasi Indeks Internet Financial Reporting Website Perusahaan Go Publik di Indonesia. Seminar Nasional Aplikasi Teknlogi Informasi, Yogyakarta, 201 Juni 2009.

Almilia, L. S. (2009b). Analisa Kualitas Isi Financial and Sustainability Reporting Pada Website Perusahaan Go Publik di Indonesia. Seminar Nasional Aplikasi Teknologi Informasi, Yogyakarta, 20 Juni 2009.

Chiu, A., Widjaja, I., \& Xiao, X. (2002). Overview and Principles of Internet Traffic Engineering.

Debei, M. M. Al. (2014). The quality and acceptance of websites: an empirical investigation in the context of higher education. International Journal of Business Information Systems, 15(2), 170.

Fikrisani, M. (2015). Analisis Faktor-Faktor Yang Mempengaruhi Tingkat Pengungkapan Internet Corpoate Reporting.
Hardianto, J. P., Ulum, I., \& Anwar, A. S. H. (2016). Analisis Faktor-Faktor Yang Memengaruhi Internet Based Corporate Governance Disclosure Pada Perusahaan Di Bursa Efek Indonesia, 6(2), 933-940.

Jensen, M. C., \& Meckling, W. H. (1976). Theory of Firm : Managerial Behavior, Agency Cost and Ownership Structure. Journal of Financial Economics, 3(4), 305-360.

Kaihatu, T. S. (2006). Good Corporate Governance dan Penerapannya di Indonesia. Jurnal Manajemen Dan Kewirausahaan, 8(1), 1-9. https://doi.org/10.9744/jmk.8.1.pp. 1-9

Kelman, H. C. (1956). Compliance \& Identification. Conflict Resolution, II(1), 51-60.

OJK. (2014). Otoritas jasa keuangan republik indonesia. Peraturan Ojk No.33, 1-29. https://doi.org/10.1016/j.jmmm.2003.12.112 7

Rizqiyah, R. N., \& Lubis, A. T. (2017). Penerapan Internet Financial Reporting (IFR) Pada Bank Umum Syariah Di Indonesia. Akuntansi Dan Keuangan Islam, 5(April), 63-82.

Wolk, et al (2001). "Signaling, Agency Theory, Accounting Policy Choice". Accounting and Business Research. Vol. 18. No 69:4756.

\begin{tabular}{|c|c|c|c|c|c|}
\hline \multicolumn{3}{|c|}{$\begin{array}{l}\text { Lampiran } \\
\text { Item Indikator Pengungkapan ICR }\end{array}$} & & & $\begin{array}{l}\text { ailiasi anggota direksi dan } \\
\text { anggota dewan komisaris dengan } \\
\text { anggota direksi / dewan komisaris } \\
\text { lainnya }\end{array}$ \\
\hline NO & KOMPONEN & \multirow{3}{*}{$\begin{array}{l}\text { ITEM PENGUNGKAPAN } \\
\text { Nama, alamat dan kontak kantor } \\
\text { pusat dan atau kantor perwakilan } \\
\text { emiten }\end{array}$} & & & \multirow[b]{2}{*}{$\begin{array}{l}\text { Nama dan alamat : akuntan } \\
\text { publik, pemeringkat efek (jika } \\
\text { ada), wali amanat, biro } \\
\text { administrasi (jika ada) }\end{array}$} \\
\hline \multirow[t]{10}{*}{1} & \multirow{2}{*}{$\begin{array}{lr}\text { Informasi } & \text { Umum } \\
\text { Emiten } & \text { Atau } \\
\text { Perusahaan } & \\
\text { Publik } & \end{array}$} & & & & \\
\hline & & & & & Dokumen anggaran dasar \\
\hline & & $\begin{array}{l}\text { Nomor telp, nomor fax, alamat } \\
\text { surat elektornik yang dapat } \\
\text { dihubungi }\end{array}$ & & & $\begin{array}{l}\text { menyajikan informasi di website } \\
\text { dalam bahasa indonesia dan } \\
\text { bahasa asing }\end{array}$ \\
\hline & & Riwanat singkat & \multirow{4}{*}{2} & & \\
\hline & & Struktur organisasi & & \multirow{3}{*}{$\begin{array}{l}\text { Informasi Bagi } \\
\text { Pemodal Atau } \\
\text { Investor }\end{array}$} & \multirow[t]{3}{*}{ Prospektus penawaran umum } \\
\hline & & Struktur kepemilikan & & & \\
\hline & & Struktur grup emiten (bagan) & & & \\
\hline & & \multirow{3}{*}{$\begin{array}{l}\text { Profil direksi, dewan omisaris, } \\
\text { komite, sekretaris perusahaan } \\
\text { (foto, nama, riwayat jabatan, } \\
\text { riwayat pendidikan dan hubungan }\end{array}$} & & & $\begin{array}{l}\text { Laporan tahunan ( } 5 \text { tahun buku } \\
\text { terakhir) }\end{array}$ \\
\hline & & & & & Laporan keuangan tahunan \\
\hline & & & & & Laporan keuangan tengah tahunan \\
\hline
\end{tabular}




\begin{tabular}{|c|c|c|}
\hline & & $\begin{array}{l}\text { Ikhtisar data keuangan penting } \\
\text { dalam bentuk perbandingan }\end{array}$ \\
\hline & & Informasi RUPS \\
\hline & & Informasi saham \\
\hline & & Infromasi obligasi/ sukuk \\
\hline & & Informasi dividen \\
\hline & & $\begin{array}{l}\text { Informasi untuk pemodal, media, } \\
\text { publik dan analis }\end{array}$ \\
\hline & & $\begin{array}{l}\text { Informasi terkait aksi korporasi } \\
\text { yang dilakukan oleh emiten }\end{array}$ \\
\hline & & $\begin{array}{l}\text { Informasi atau fakta material } \\
\text { selain yang telah diungkapkan } \\
\text { dalam peraturan OJK }\end{array}$ \\
\hline \multirow[t]{12}{*}{3} & $\begin{array}{ll}\text { Informasi } & \text { Tata } \\
\text { Kelola } & \\
\text { Perusahaan } & \\
\end{array}$ & $\begin{array}{l}\text { Pedoman kerja direksi dan dewan } \\
\text { komisaris }\end{array}$ \\
\hline & & $\begin{array}{l}\text { Pengangkatan, pemberhentian } \\
\text { atau kekosongan sekretaris } \\
\text { perusahaan }\end{array}$ \\
\hline & & Piagam unit audit internal \\
\hline & & Kode Etik \\
\hline & & Pedoman kerja komite \\
\hline & & $\begin{array}{l}\text { Pengangkata dan pemberhentian } \\
\text { anggota komite audit }\end{array}$ \\
\hline & & $\begin{array}{l}\text { Uraian prosedur nominasi dan } \\
\text { remunerasi }\end{array}$ \\
\hline & & Kebijakan manajemen resiko \\
\hline & & $\begin{array}{l}\text { Kebijakan mekanisme sistem } \\
\text { pelaporan pelanggaran }\end{array}$ \\
\hline & & Kebijakan anti korupsi \\
\hline & & $\begin{array}{l}\text { Kebijakan terkait seleksi pemasok } \\
\text { dan hak reditur }\end{array}$ \\
\hline & & $\begin{array}{l}\text { Kebijakan dalam peningkatan } \\
\text { kemampuan vendor }\end{array}$ \\
\hline \multirow[t]{5}{*}{4} & $\begin{array}{l}\text { Informasi } \\
\text { Tanggung Jawab } \\
\text { Sosial Perusahaan } \\
\end{array}$ & $\begin{array}{l}\text { Kebijakan, jenis program dan } \\
\text { biaya yang dikeluarkan, meliputi : }\end{array}$ \\
\hline & & $\begin{array}{ll}- & \text { Lingkungan hidup } \\
\end{array}$ \\
\hline & & $\begin{array}{l}\text { Praktik ketenagaerjaan, } \\
\text { kesehatan dan } \\
\text { keselamatan kerja }\end{array}$ \\
\hline & & $\begin{array}{ll}- & \begin{array}{l}\text { Pengembangan sosial } \\
\text { dan kemasyarakatan }\end{array}\end{array}$ \\
\hline & & $\begin{array}{ll}\text { - } & \text { Tanggungjawab produk } \\
\text { dan atau layanan } \\
\text { disertai dengan } \\
\text { informasi } \\
\text { pendukungnya. }\end{array}$ \\
\hline
\end{tabular}

\section{INFORMASI UMUM EMITEN ATAU PERUSAHAAN PUBLIK}

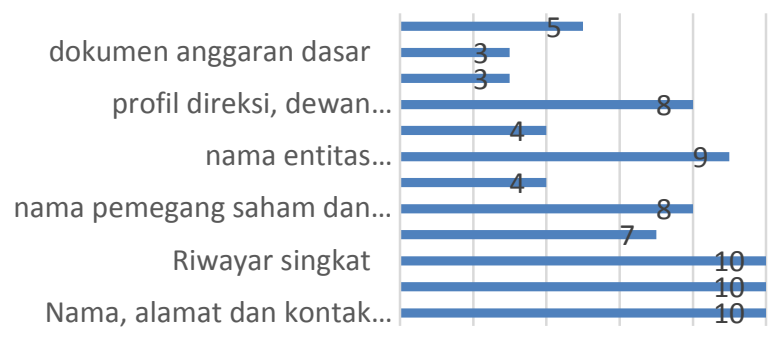

$\begin{array}{llllll}0 & 2 & 4 & 6 & 8 & 10\end{array}$

\section{INFORMASI BAGI PEMODAL ATAU INVESTOR}

Ikhtisar data keuangan dalam bentuk perbandingan

rasio liabilitas terhadap. rasio laba terhadap ekuitas,

laba per saham,

ikhtisar data keuangan dalam...

Prospek penawaran umum

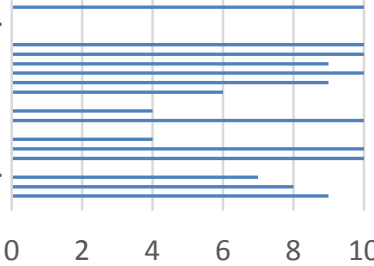

\section{INFORMASI BAGI PEMODAL/INVESTOR \\ Informasi RUPS, informasi saham dan informasi sukuk}

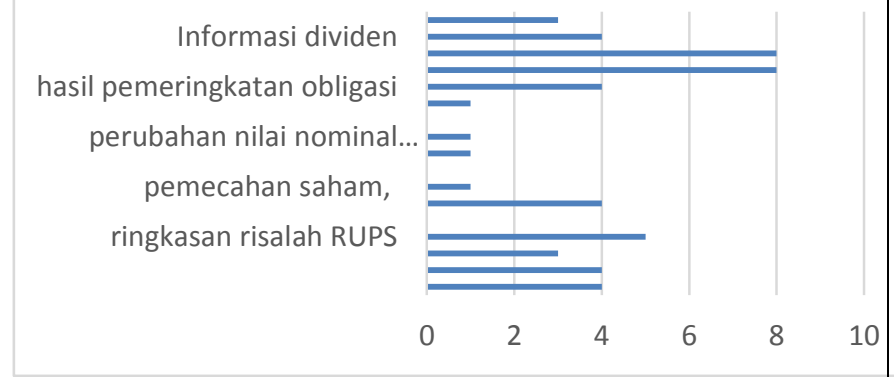




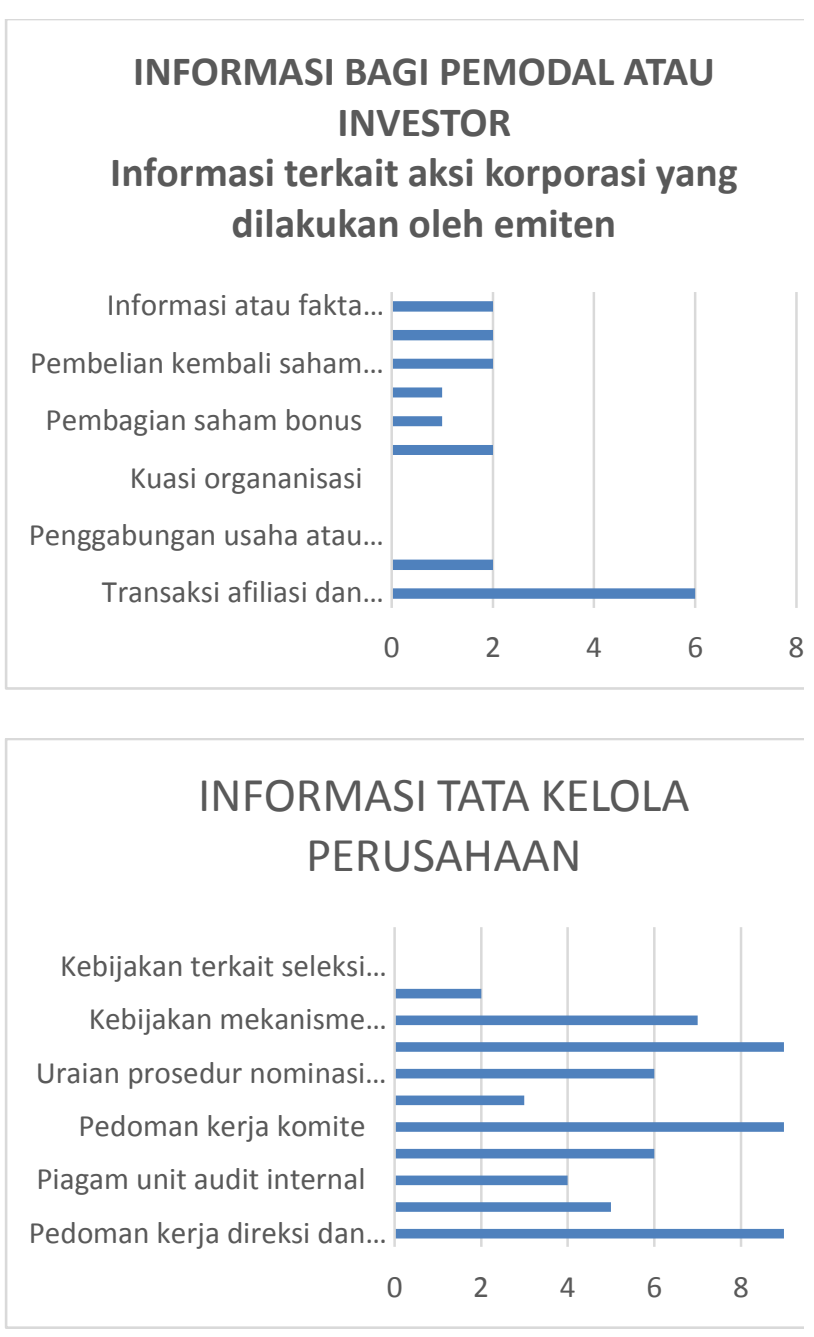


Jurnal Ilmiah Ekonomi Islam, 4(03), 2018, 14

INFORMASI TANGGUNGJAWAB

SOSIAL PERUSAHAAN

Tanggungjawab produk dan atau layanan disertai...

Pengembangan sosial dan kemasyarakatan

Praktik ketenagaerjaan, kesehatan dan...

Lingkungan hidup

$\begin{array}{lllllll}0 & 2 & 4 & 6 & 8 & 10 & 12\end{array}$ 